\title{
Learning Media Using Camtasia Studio 8 Video to Improve Student Learning Outcomes in Basic Schools
}

\author{
lin Indrayani \\ SD Islam Al Azhar 22 Salatiga \\ indrayani2785@gmail.com
}

\section{Article History}

accepted 14/11/2020

approved $21 / 11 / 2020$

published $26 / 11 / 2020$

\begin{abstract}
This research is a Classroom Action Research (CAR) which consists of two cycles. The research subjects were fourth grade students in class IV C Al Azhar 22 Islamic Elementery School Salatiga, Central Java with the total of students are 24 students. The Data collection techniques using test and non-test techniques. The assessment instrument used items and observations of the scoring rubric. Analysis of the data used in the study included a comparative descriptive technique, namely a statistical technique by comparing the scores between cycles, the mean, the minimum score, the maximum, and the percentage. The results of the study that used the video powerpoint Camtasia Studio 8 media can improve student learning outcomes in the Theme 5 My Hero class IV C Al Azhar 22 Islamic Elementery School Salatiga. The conclusion of this study that used the video powerpoint of Camtasia Studio 8 media can improve student learning outcomes in the theme 5 My Hero class IV C Al Azhar 22 Islamic Elementery School Salatiga. And the suggestions for the teachers, they should be able to use the Camtasia Studio 8 powerpoint media according to the steps in thematic subjects, so that it can improve the active participation from students, generate ideas, mastery of concepts and can improve students thematic learning outcomes.
\end{abstract}

Keywords: learning media, camtasia studio 8 videos, learning outcomes

\begin{abstract}
Abstrak
Penelitian ini merupakan penelitian tindakan kelas (PTK) yang terdiri dari dua siklus. Subyek penelitian adalah siswa kelas IV C SD Islam AI Azhar 22 Salatiga Jawa Tengah dengan jumlah siswa 24 anak. Teknik pengumpulan data dengan teknik tes dan non tes. Adapun instrumen penilaiannya menggunakan butir-butir soal dan pengamatan rubrik penilaian. Analisa data yang digunakan dalam penelitian meliputi teknik deskriptif komparatif yakni teknik statistik dengan membandingkan skor antar siklus, mean, skor minimal, maksimal, dan persentase. Hasil penelitian bahwa Penggunaan media video powerpoint camtasia Studio 8 dapat meningkatkan hasil belajar siswa pada Tema 5 Pahlawanku kelas IV C SD Islam Al Azhar 22 Salatiga. Kesimpulan dari penelitian ini adalah menggunakan media video powerpoint camtasia Studio 8 dapat meningkatkan hasil belajar siswa pada Tema 5 Pahlawanku kelas IV C SD Islam Al Azhar 22 Salatiga. Saran bagi guru hendaknya guru dapat menggunakan media video powerpoint camtasia Studio 8 sesuai langkah-langkahnya pada mata pelajaran tematik sehingga dapat meningkatkan partisipasi aktif, memunculkan ide, penguasaan konsep dan meningkatkan hasil belajar tematik siswa.
\end{abstract}

Kata kunci: media pembelajaran, video camtasia studio 8, hasil belajar

Social, Humanities, and Education Studies (SHEs): Conference Series https://jurnal.uns.ac.id/shes 


\section{PENDAHULUAN}

Pendidikan merupakan salah satu bidang yang terus berkembang seiring dengan perkembangan ilmu pengetahuan dan teknologi (iptek). Oleh karena itu pembaharuan pada bidang pedidikan sangat penting untuk dilakukan. Upaya pembaharuan yang dapat dilakukan salah satunya adalah penyelenggaraan pendidikan pada semua jenjang dan jenis pendidikan harus mampu mencapai tujuan pendidikan yang diharapkan. Sehingga sumber daya manusia yang dihasilkan dapat menghadapi perkembangan yang terjadi karena sumber daya manusia adalah salah satu aspek yang sangat besar perannya dalam kemajuan suatu bangsa. Semakin berkualitas sumber daya manusia yang dimiliki, maka semakin maju bangsa tersebut.

Media pembelajaran merupakan salah faktor penting dalam peningkatan kualitas pembelajaran. Hal tersebut disebabkan adanya perkembangan teknologi dalam bidang pendidikan yang menuntut efisiensi dan efektivitas dalam pembelajaran. Untuk mencapai tingkat efisiensi dan efektivitas yang optimal, salah satu upaya yang perlu dilakukan adalah mengurangi bahkan jika perlu menghilangkan dominasi sistem penyampaian pelajaran yang bersifat verbalistik dengan cara menggunakan media pembelajaran. Sehubungan dengan penggunaan media dalam kegiatan pembelajaran, para tenaga pengajar atau guru perlu cermat dalam pemilihan dan atau penetapan media yang akan digunakannya. Kecermatan dan ketepatan dalam pemilihan media akan menunjang efektivitas kegiatan pembelajaran yang dilakukannya. Di samping itu juga kegiatan pembelajaran menjadi menarik sehingga dapat menimbulkan motivasi belajar, dan perhatian siswa menjadi terpusat kepada topik yang dibahas dalam kegiatan pembelajaran yang dilakukannya.Kecermatan dan ketepatan dalam memilih media pembelajaran dipengaruhi oleh banyak faktor seperti luas sempitnya pengetahuan dan pemahaman tenaga pengajar tentag kriteria dan faktor-faktor yang perlu dipertimbangkan serta prosedur pemilihan media pembelajaran. Uraian berikut akan membahas hal-hal dimaksud agar kita dalam memilihan media pembelajaran lebih tepat. Dan media pembelajaran dapat dikatakan sebagai semua alat yang dapat digunakan sebagai media dalam pembelajaran.

Berdasarkan pengalaman peneliti, selama ini peneliti belum mengajar menggunakan video pembelajaran. Media pembelajaran yang digunakan dalam mengajar adalah powerpoint pembelajaran. Hal ini menyebabkan siswa bosan dan tidak mempelajari powerpoint yang disiapkan oleh guru, karena tidak semua siswa memiliki pemahaman membaca dengan tepat. Oleh karena itu peneliti bermaksud mengembangkan media pembelajaran menggunakan video pembelajaran, karena dengan mengajar menggunakan video, siswa yang memiliki kegemaran belajar secara visual maupun audiovisual dapat terpenuhi kebutuhan belajarnya.

SD Islam Al Azhar 22 Salatiga menentukan kriteria ketuntasan minimal (KKM) pada mata pelajaran Tematik adalah 75. Sementara itu, hasil Tematik pada siswa kelas IVC yang berjumlah 24 anak rata-rata 70,25 yang mencapai KKM adalah (67\%) dan yang tidak mencapai KKM (33\%), ini berarti KKM belum tuntas, karena KKM dianggap tuntas apabila persentase nilai siswa yang mencapai KKM (75\%).

Berdasarkan uraian di atas, maka peneliti ingin melakukan penelitian lebih lanjut dengan judul "Pengembangan media Pembelajaran Tematik Menggunakan Video Camtasia Studio 8 pada Tema 5 Pahlawanku untuk Meningkatkan Hasil Belajar Siswa Kelas IVC (Penelitian Tindakan Kelas di SD Islam Al Azhar 22 Salatiga Semester I Tahun Pelajaran 2020/2021)"

Kemendikbud (2013:193) pembelajaran tematik dilaksanakan dengan menggunakan prinsip pembelajaran terpadu. Pembelajaran terpadu menggunakan tema sebagai pemersatu kegiatan pembelajaran yang memadukan beberapa mata pelajaran sekaligus dalam satu kali tatap muka, untuk memberikan pengalaman yang bermakna bagi siswa. Karena siswa dalam memahami sebuah konsep yang mereka pelajari selalu melalui pengalaman langsung dan menghubungkannya dengan konsep lain yang telah dikuasainya. Menurut Rusman (2012), pembelajaran tematik adalah model pembelajaran 
terpadu (integrated instruction) yang merupakan suatu sistem pembelajaran yang memungkinkan siswa baik secara individual maupun kelompok aktif menggali dan menemukan konsep serta prinsip- prinsip keilmuan secara holistik, bermakna dan otentik.

Berdasarkan beberapa pendapat di atas, penulis menyimpulkan bahwa pembelajaran tematik yaitu pembelajaran terpadu yang mengaitkan beberapa materi dari beberapa mata pelajaran dalam satu topik/ tema sehingga dapat memberikan pengalaman belajar yang bermakna.

Media pembelajaran berasal dari bahasa latin dan merupakan bentuk jamak dari kata medium yang secara harfiah berarti perantara atau pengantar. Sedangkan Menurut Asosiasi Pendidikan Nasional menyatakan media adalah bentuk-bentuk komunikasi baik tercetak maupun audiovisual serta peralatannya. Dimana media hedaknya dapat memanipulasi, dapat dilihat, didengar dan dibaca (Arief S Sadiman. Dkk, 2006:7). Media merupakan salah satu komponen komunikasi, yaitu sebagai pembawa pesan dari komunikator menuju komunikan (Criticos, 1996) dalam Santyasa, (2007). Video cd Intraktif multimedia atau disebut media pembelajaran cd interaktif berbasis video yang membutuhkan personal computers. Dalam video cd interaktif mutimedia ini adalah inovasi sebuah media yang menampilkan cara atau langkah-langkah pembuatan html web yang dapat mempermudah siswa untuk memahami dan mengaplikasikan, kemudian dapat merangsang siswa lebih aktif disisi lain siswa tidak perlu lagi sulit untuk membaca buku tingal mengikuti langkah cara pembuatan html web dengan media video cd Intraktif multimedia. Rayandra Asyhar (2012:74) berpendapat "video merupakan rekaman gambar dan suara dalam kaset pita video kedalam vita magnetik. Media Video dirancang untuk menghasilkan gambar yang realistis dunia sekitar kita".

Arsyad (2008) berpendapat bahwa konsep interaktif paling erat kaitannya dengan media berbasis komputer, interaksi dalam lingkungan pembelajaran berbasis komputer umumnya mengikuti tiga unsur yaitu: 1) urut-urutan instruksional yang dapat diurutkan, 2) jawaban/respon atau pekerjaan siswa dan 3) umpan balik yang dapat disesuaikan. Media interaktif biasanya mengacu pada produk dan layanan pada sistem berbasis komputer digital yang merespon tindakan pengguna dengan menyajikan konten seperti teks, grafik, animasi, video, audio, dan lain-lain. Camtasia studio merupakan perangkat lunak (software) yang dikembangkan oleh TechSmith Coorporation khusus bidang multimedia.

Camtasia Studio adalah program aplikasi yang dikemas untuk recording, editing, dan publishing dalam membuat video presentasi yang ada pada layar (screen) komputer. Camtasia studio adalah software untuk meng capture tampilan layar monitor, dengan ditambahi audio dan video, bisa juga kita gunakan untuk merekam hasil presentasi powerpoint ke dalam format video. Camtasia Studio dapat membantu dan melatih kita dalam menyampaikan serta berinteraksi dengan audiens. Camtasia Studio memiliki kemampuan untuk merekam suara yang ada dalam layar,termasuk kegiatan di desktop, presentasi powerpoint, narasi suara, dan webcam video. Camtasia Studio adalah salah satu solusi lengkap untuk menciptakan video profesional dan aktivitas desktop PC dengan cepat. Siapapun dapat merekam dan menciptakan satu pelajaran penuh video gerak atau presentasi. Video tutorial merupakan panduan tentang cara menjelaskan sesuatu, baik materi pembelajaran atau pelatihan (training) maupun proses pengoprasian suatu sistem (hardware dan software) yang dikemas dalam bentuk video. Format sajian ini merupakan multimedia pembelajaran yang dalam penyampaian materinya dilakukan secara tutorial, sebagaimana layaknya tutorial yang dilakukan oleh guru atau instruktur. Informasi yang berisi suatu konsep disajikan dengan teks, gambar, baik diam atau bergerak dan grafik. Pada saat yang tepat, yaitu ketika dianggap bahwa pengguna telah membaca menginterprestasikan dan menyerap konsep itu, diajukan serangkaian dan tugas. Jika jawaban atau respon siswa benar, kemudian dilanjutkan dengan materi berikutnya. jika jawaban atau respon siswa salah, maka siswa harus mengulang memahami konsep tersebut secara keseluruhan ataupun pada bagianbagian tertentu saja (remedial). 
Kemudian pada bagian akhir biasanya akan diberikan serangkaian pertanyaan yang untuk mengukur tingkat pemahaman siswa atas konsep atau materi yang disampaikan. Tutorial atau tutoring adalah bantuan atau bimbingan belajar yang bersifat akademik oleh tutor kepada siswa untuk membantu kelancaran proses belajar madiri siswa secara perorangan atau kelompok berkaitan dengan materi ajar. Tutorial dilaksanakan secara tatap muka atau jarak jauh berdasarkan konsep belajar mandiri. Belajar mandiri dalam tutorial mengandung pengertian, bahwa tutorial merupakan bantuan belajar dalam upaya memicu dan memacu kemandirian, disiplin, dan inisiatif diri siswa dalam belajar dengan minimalisasi intervensi dari pihak pembelajar yang dikenal sebagai tutor. Prinsip pokok tutorial adalah "kemandirian siswa". Tutorial tidak ada, jika kemandirian tidak ada. Jika siswa tidak belajar di rumah, dan datang ke tutorial dengan 'kepala kosong', maka yang terjadi adalah "pembelajaran" biasa, bukan tutorial. Jadi video tutorial adalah salah satu media pembelajaran yang berfungsi untuk melakukan pertukaran informasi antara pengirim dan penerima sehingga tercapainya suatu tujuan yang dikehendaki. Mata pelajaran pemrograman web Pemrograman web disini diambil dari 2 suku.

Menurut Nana Sudjana (2008) mengemukakan penilaian hasil belajar mengisyaratkan bahwa hasil belajar sebagai objek yang menjadi sasaran penilaian. Hasil belajar sebagai objek penilaian pada hakikatnya menilai penguasaan siswa terhadap tujuan-tujuan intruksional, karena rumusan tujuan intruksional menggambarkan hasil belajar yang harus dikuasai siswa berupa kemampuan-kemampuan siswa setelah menerima atau menyelesaikan pengalaman belajarnya. Hasil belajar sebagai objek penilaian pada hakikatnya menilai penguasaan siswa terhadap tujuan-tujuan intruksional, karena rumusan tujuan intruksional menggambarkan hasil belajar yang harus dikuasai siswa berupa kemampuan-kemampuan siswa setelah menerima atau menyelesaikan pengalaman belajarnya. Sedangkan Bloom, dkk (dalam Asep Heri Hernawan, 2009) menggolongkan hasil belajar menjadi tiga, yaitu kognitif, afektif, dan psikomotor.

Dari beberapa pengertian hasil belajar, penulis menyimpulkan bahwa hasil belajar adalah tanda atau bukti yang diperoleh siswa yang berguna untuk mengukur kemampuan siswa setelah selesai pembelajaran.

Rumusan Masalah

Apakah dengan menggunakan media video powerpoint camtasia Studio 8 dapat meningkatkan hasil belajar siswa pada Tema 5 Pahlawanku kelas IV C SD Islam Al Azhar 22 Salatiga?

Tujuan Penelitian

Mendeskripsikan pengembangan media pembelajaran menggunakan video camtasia studio pada pembelajaran tematik Tema 5 Pahlawanku kelas IVC SD Islam Al Azhar 22 Salatiga. Mendeskripsikan langkah-langkah pembuatan video menggunakan camtasia studio 8. Mengetahui hasil belajar Tematik kelas IVC SD Islam Al Azhar 22 Salatiga dengan video camtasia studio 8.

\section{METODE}

Penelitian Tindakan Kelas (PTK) yang digunakan peneliti adalah jenis PTK kolaboratif. PTK kolaboratif yaitu kerja sama antara peneliti dengan teman sejawat, ide berasal dari peneliti dan yang melakukan tindakan adalah guru mata pelajaran tematik kelas IVC SD Islam AI Azhar 22 Salatiga di lakukan pada semester I. Unit penelitian adalah kelas IVC SD Islam Al Azhar 22 Salatiga.

Penelitian ini dilaksanakan pada semester I tahun pelajaran 2020/2021. Subjek dalam penelitian ini adalah siswa kelas IV C SD Islam Al Azhar 22 Salatiga Jawa Tengah dengan jumlah siswa 24 anak.

Teknik pengumpulan data yang dipakai dalam penelitian tindakan ini adalah teknik tes dan non tes yang terdiri dari: 
a. Tes berbentuk pilihan ganda, digunakan untuk mengukur kemampuan siswa setelah diberi strategi media video power point camtasia studio 8.

b. Non tes dalam penelitian ini berupa pengamatan implementasi RPP, pengamatan aktivitas siswa dan penilaian proses.

1) Pengamatan implementasi RPP digunakan untuk mendapat data tentang pengajaran guru didalam kelas serta pengamatan keaktifan siswa, sehingga bisa dilihat di dalam pelaksanaan pembelajaran benar-benar sesuai dengan kondisi dan proses yang diharapkan.

2) Pengamatan melalui diskusi dan presentasi dilakukan terhadap proses pembelajaran dengan menggunakan media video power point camtasia studio 8.

3) Dokumentasi digunakan untuk mendapatkan data tentang identitas dari siswa. Dalam hal ini data yang diperoleh adalah daftar siswa menonjol baik dari segi positif maupun negatifnya.

Teknik analis data yang peneliti gunakan dalam penelitian untuk mengetahui tingkat keberhasilan belajar siswa kelas IVC SD Islam Al Azhar 22 Salatiga menggunakan Video Camtasia Studio 8 yaitu teknik deskriptif komparatif yakni teknik statistik dengan membandingkan skor antar siklus, persentase, mean, skor minimal, maksimal.

Siklus I

\section{HASIL DAN PEMBAHASAN}

Penelitian yang telah dilakukan akhirnya diperoleh data-data yang dapat diuraikan sebagai berikut:

a. Perencanaan Penelitian

Kegiatan yang dilakukan dalam tahapan ini adalah menyiapkan segala sesuatu yang diperlukan dalam melaksanakan skenario pembelajaran siklus I yang telah direncanakan. Kegiatan yang dilakukan antara lain:

1) Membuat Rencana Pelaksanaan Pembelajaran (RPP) dengan materi Tematik Tema 5 Pahlawanku.

2) Menyiapkan lembar observasi (pengamatan) sebagai pedoman atas proses pembelajaran menggunakan video powerpoint.

3) Menyusun soal tes untuk menilai peningkatan hasil belajar siswa terhadap materi yang diajarkan.

b. Pelaksanaan Tindakan

Dilakukan 2 kali yaitu pada tanggal 2 dan 3 Nopember 2020. Deskripsi pelaksanaan tindakan pembelajaran adalah sebagai berikut :

1) Pertemuan Pertama

Kegiatan pembelajaran diawali oleh guru mengucapkan salam, dilanjutkan peserta didik menjawab salam dengan serempak. Guru meminta salah satu peserta didik untuk memimpin ikrar dan do'a, setelah selesai, guru memberikan motivasi dengan mengajak peserta didik untuk menyanyikan lagu "Maju Tak Gentar". Kemudian guru mengajak dan mengingatkan kepada peserta didik untuk mematuhi protokol kesehatan. Setelah itu dilanjutkan dengan mengabsen peserta didik dan guru mulai membuka pelajaran dengan mencoba mengingatkan kembali materi sebelumnya. Guru mulai masuk kedalam kegiatan pembelajaran. Guru bersama siswa belajar dengan media pembelajaran berupa Ms.Power Point yang dituangkan guru dalam video Power Point dan dijelaskan ke siswa, namun dalam LMS juga di upload video Power Point agar siswa bisa belajar dengan mandiri. Guru menjelaskan materi melalui video Power Point yang di share screen melalui zoom. Siswa diminta untuk mencermati video tersebut. Guru membagi siswa ke dalam 4 kelompok. Siswa diminta mengakses LMS dengan link http://www.sdia22salatiga.co.id dan membuka forum diskusi. Siswa berdiskusi dengan kelompok dengan membahas topik yang sudah diupload guru dalam forum diskusi tersebut. Setelah diskusi selesai, perwakilan dari kelompok diminta untuk mempresentasikan hasil diskusi dari kelompoknya masing-masing. 
Guru memberikan penguatan. Kemudian, guru melanjutkan menjelaskan meteri berikutnya. Siswa diminta untuk mendownload LKPD I yang ada di LMS dan mengerjakannya serta mengupload kembali LKPD tersebut pada fitur Assigment yang terdapat dalam LMS (Moodle). Sebelum mengakhiri pembelajaran guru mengingatkan pada peserta didik bahwa pada pertemuan berikutnya akan diadakan ulangan atau evaluasi dengan materi yang telah diajarkan. Setelah itu guru mengakhiri pelajaran dengan salam dan dijawab serempak oleh peserta didik.

\section{2) Pertemuan kedua}

Guru mengawali pelajaran dengan salam, peserta didik menjawab serempak. Guru meminta salah satu siswa memimpin ikrar dan do'a, setelah selesai, guru mengabsen peserta didik. Guru mulai masuk kedalam kegiatan pembelajaran. Guru bersama siswa belajar dengan media pembelajaran berupa Ms.Power Point yang dituangkan guru dalam video Power Point dan dijelaskan ke siswa, namun dalam LMS juga di upload video Power Point agar siswa bisa belajar dengan mandiri. Guru menjelaskan materi melalui video Power Point yang di share screen melalui Zoom. Siswa diminta untuk mencermati video tersebut. Guru membimbing siswa untuk mengakses LMS (Moodle) dengan link http://www.sdia22salatiga.co.id. Guru mengarahkan siswa untuk membuka fitur assignment dan mondownload LKPD II. Siswa diminta mengerjakan LKPD tersebut dan mengupload kembali pada LMS(Moodle). Guru memberikan kesempatan kepada siswa untuk bertanya tentang materi yang belum dipahami. Guru meminta siswa untuk mengakses kembali LMS dan mengerjakan evaluasi melalui google form. Pada evaluasi siklus I diikuti oleh semua peserta didik kelas IV, yakni sebanyak 24 peserta didik. Peserta didik diberi waktu 30 menit untuk mengerjakan soal evaluasi melalui google form yang linknya tercantum dalam LMS(Moodle). Guru mengakhiri pelajaran dengan salam.

Berdasarkan latar belakang penelitian ini, hasil pembelajaran tematik tema 5 pada siswa kelas 4C yang berjumlah 24 siswa, sebelum menggunakan media berupa video power point Camtasia studio 8, rata - rata yang diperoleh adalah 70,25. Siswa yang mencapai KKM adalah 67\% dan siswa yang belum mencapai KKM adalah $33 \%$, sehingga dapat diartikan KKM belum tuntas, karena KKM dianggap tuntas adalah jika mencapai minimal $75 \%$.

Observasi

Hasil observasi yang dilakukan oleh observer selama jalannya kegiatan pembelajaran dan mengamati hasil evaluasi pada akhir kegiatan siklus pertama belum berhasil karena siswa yang tuntas hanya 17 siswa dari 24 siswa. Siswa yang sudah tuntas baru mencapai $71 \%$.

\section{Refleksi}

Hasil belajar pada siklus I mengalami peningkatan dibandingkan dengan keadaan awal yang disajikan pada latar belakang masalah. Hasil tes awal siswa yang tuntas mencapai $67 \%$, sedangkan pada hasil evaluasi siklus I siswa yang tuntas mencapai $71 \%$. $\mathrm{Hal}$ ini menunjukkan ada peningkatan hasil belajar siswa sebesar $4 \%$.

Dari deskripsi di atas menunjukkan bahwa hasil rata-rata kelas meningkat pada siklus I, namun belum dikatakan berhasil dalam pembelajaran Tema 5 karena siswa yang tuntas (KKM) belum mencapai 75\%. Berdasarkan hal tersebut, maka masih diperlukan perbaikan pembelajaran dengan media yang sama pada Siklus II. Berdasarkan hasil tes awal dan evaluasi siklus 1 tersebut, dapat dilihat presentase ketuntasan belajar siklus 1 sebagai berikut : 
Tabel 1. Persentase Ketuntasan Belajar Siklus I

\begin{tabular}{ccccccc}
\hline \multirow{2}{*}{ No } & & \multicolumn{2}{c}{ Siswa yang Tuntas } & \multicolumn{2}{c}{ Siswa Belum Tuntas } \\
\cline { 3 - 6 } & Uraian & & Frekuensi & Persentase & Frekunsi & Persentase \\
\hline $\begin{array}{l}\text { 1 Kondisi } \\
\text { dengan }\end{array}$ & $\begin{array}{c}\text { Awal } \\
\text { keadaan }\end{array}$ & $\begin{array}{c}\text { (sesuai } \\
\text { padar belakang) }\end{array}$ & 16 & $67 \%$ & 8 & $33 \%$ \\
2 Siklus I & & 17 & & & \\
\hline
\end{tabular}

Tabel di atas dapat dijelaskan siswa yang belum tuntas belajar adalah sebagai berikut : 1. Pada kondisi awal sesuai dengan latar belakang penelitian, siswa yang belum tuntas sebanyak 8 siswa dari 24 siswa atau 33\%.

2. Pada siklus 1 , siswa yang belum tuntas sebanyak 7 siswa dari 24 siswa atau $29 \%$.

Sedangkan siswa yang tuntas belajar adalah sebagai berikut:

1. Pada kondisi awal sesuai dengan latar belakang penelitian, siswa yang tuntas sebanyak 16 siswa dari 24 siswa atau $67 \%$.

2. Pada siklus 1 , siswa yang tuntas sebanyak 17 siswa dari 24 siswa atau $71 \%$. berikut :

Berdasarkan tabel diatas dapat dibuat diagram batang hasil belajar siklus 1 sebagai

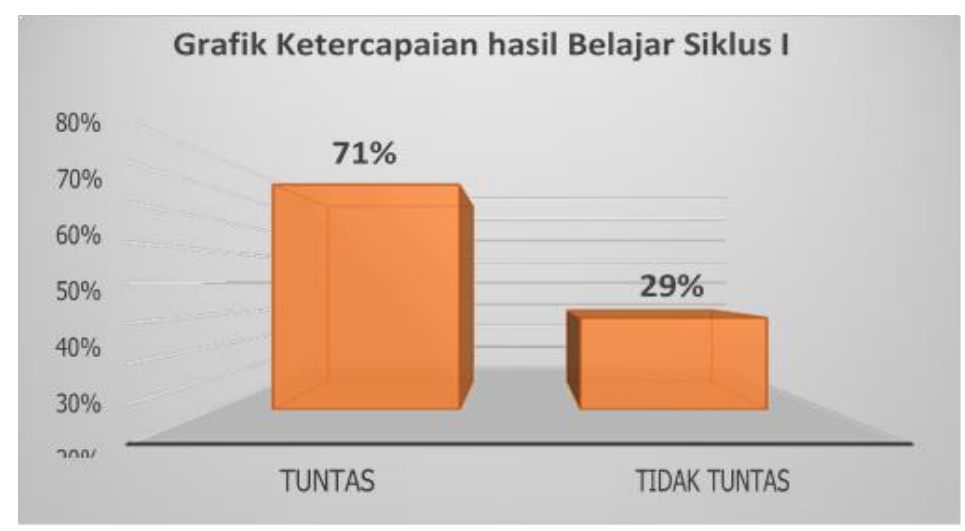

Siklus II

Gambar 1. Grafik ketercapaian hasil belajar siklus I

Penelitian yang telah dilakukan akhirnya diperoleh data-data yang dapat diuraikan sebagai berikut:

a. Perencanaan Penelitian

Kegiatan yang dilakukan dalam tahapan ini adalah menyiapkan segala sesuatu yang diperlukan dalam melaksanakan skenario pembelajaran siklus I yang telah direncanakan. Kegiatan yang dilakukan antara lain:

1) Membuat Rencana Pelaksanaan Pembelajaran (RPP) dengan materi Tematik Tema 5 Pahlawanku.

2) Menyiapkan lembar observasi (pengamatan) sebagai pedoman atas proses pembelajaran menggunakan video powerpoint.

3) Menyusun soal tes untuk menilai peningkatan hasil belajar siswa terhadap materi yang diajarkan.

b. Pelaksanaan Tindakan

Dilakukan 2 kali yaitu pada tanggal 9 dan 10 Nopember 2020. Deskripsi pelaksanaan tindakan pembelajaran adalah sebagai berikut :

1) Pertemuan Pertama

Kegiatan pembelajaran diawali oleh guru mengucapkan salam, dilanjutkan peserta didik menjawab salam dengan serempak. Guru meminta salah satu peserta didik untuk 
memimpin ikrar dan do'a, setelah selesai, guru memberikan motivasi dengan mengajak peserta didik untuk menyanyikan lagu "Maju Tak Gentar". Kemudian guru mengajak dan mengingatkan kepada peserta didik untuk mematuhi protokol kesehatan. Setelah itu dilanjutkan dengan mengabsen peserta didik dan guru mulai membuka pelajaran dengan mencoba mengingatkan kembali materi sebelumnya. Guru mulai masuk kedalam kegiatan pembelajaran. Guru bersama siswa belajar dengan media pembelajaran berupa Ms.Power Point yang dituangkan guru dalam video Power Point dan dijelaskan ke siswa, namun dalam LMS juga di upload video Power Point agar siswa bisa belajar dengan mandiri. Guru menjelaskan materi melalui video Power Point yang di share screen melalui zoom. Guru menyangkan teks bacaan melalui slide power point yang di share screen melalui zoom. Salah satu siswa diminta membacakan teks tersebut. Guru dan siswa bertanya jawab secara aktif melalui zoom. Guru kemudian menayangkan gambar salah satu tokoh pahlawan nasional pada slide power point melalui share screen pada zoom. Siswa diminta mengamati gambar tersebut dan mengemukakan 3 informasi yang bisa diperoleh berdasarkan gambar tersebut secara lagsung melalui zoom. Guru membagi siswa ke dalam 4 kelompok. Siswa diminta mengakses LMS dengan link http://www.sdia22salatiga.co.id dan membuka forum diskusi. Siswa berdiskusi bersama kelompok dengan membahas topik yang sudah diupload guru dalam forum diskusi tersebut. Setelah diskusi selesai, perwakilan dari kelompok diminta untuk mempresentasikan hasil diskusi dari kelompoknya masing-masing. Guru memberikan penguatan. Kemudian, guru melanjutkan menjelaskan meteri berikutnya. Siswa diminta untuk mendownload LKPD I yang ada di LMS dan mengerjakannya serta mengupload kembali LKPD tersebut pada fitur Assigment yang terdapat dalam LMS (Moodle). Sebelum mengakhiri pembelajaran guru mengingatkan pada peserta didik bahwa pada pertemuan berikutnya akan diadakan ulangan atau evaluasi dengan materi yang telah diajarkan. Setelah itu guru mengakhiri pelajaran dengan salam dan dijawab serempak oleh peserta didik.

2) Pertemuan kedua

Guru mengawali pelajaran dengan salam, peserta didik menjawab serempak. Guru meminta salah satu siswa memimpin ikrar dan do'a, setelah selesai, guru mengabsen peserta didik. Guru mulai masuk kedalam kegiatan pembelajaran. Guru bersama siswa belajar dengan media pembelajaran berupa Ms.Power Point yang dituangkan guru dalam video Power Point dan dijelaskan ke siswa, namun dalam LMS juga di upload video Power Point agar siswa bisa belajar dengan mandiri. Guru menjelaskan materi melalui video Power Point yang di share screen melalui Zoom. Siswa diminta untuk mencermati video tersebut. Guru membimbing siswa untuk mengakses LMS (Moodle) dengan link http://www.sdia22salatiga.co.id. Guru mengarahkan siswa untuk membuka fitur assignment dan mondownload LKPD II. Siswa diminta untuk melakukan percobaan sederhana LKPD tersebut dan mengupload kembali pada LMS(Moodle). Guru memberikan kesempatan kepada siswa untuk bertanya tentang materi yang belum dipahami. Guru meminta siswa untuk mengakses kembali LMS dan mengerjakan evaluasi melalui google form. Pada evaluasi siklus II diikuti oleh semua peserta didik kelas IV, yakni sebanyak 24 peserta didik. Peserta didik diberi waktu 30 menit untuk mengerjakan soal evaluasi melalui google form yang linknya tercantum dalam LMS(Moodle). Guru mengakhiri pelajaran dengan salam.

c. Observasi

Hasil observasi yang dilakukan oleh observer selama jalannya kegiatan pembelajaran dan mengamati hasil evaluasi pada akhir kegiatan siklus kedua bisa dikatakan sudah berhasil karean siswa yang tuntas sebanyak18 siswa dari 24 siswa. Dengan kata lain siswa yang tuntas sudah mencapai $75 \%$. Namun, meskipun ketuntasan sudah mencapai $75 \%$ masih diperlukan perbaikan karena masih ada 6 siswa yang nilainya di bawah KKM.

d. Refleksi

Hasil belajar pada siklus II mengalami peningkatan dibandingkan dengan siklus I. Hasil evaluasi siklus I siswa yang tuntas mencapai $71 \%$, sedangkan pada hasil evaluasi siklus II siswa yang tuntas mencapai $75 \%$. Hal ini menunjukkan ada peningkatan hasil 


\section{SHEs: Conference Series 3 (3) (2020) 626-635}

belajar siswa sebesar 4\%. Dari deskripsi di atas menunjukkan bahwa hasil rata-rata kelas meningkat pada siklus II, dengan kata lain dapat dikatakan berhasil dalam pembelajaran Tema 5 karena siswa yang tuntas (KKM) sudah mencapai 75\%. Meskipun demikian, masih diperlukan perbaikan pembelajaran dengan media yang sama pada siklus III.

Berdasarkan hasil evaluasi siklus II tersebut, dapat dilihat presentase ketuntasan belajar siklus II sebagai berikut :

Tabel 2. Persentase Ketuntasan Belajar Siklus II

\begin{tabular}{ccccc}
\hline & Uraian & \multicolumn{2}{c}{$\begin{array}{c}\text { Siswa yang Tuntas } \\
\text { Frekuensi }\end{array}$} & \multicolumn{2}{c}{$\begin{array}{c}\text { Siswa Belum Tuntas } \\
\text { No }\end{array}$} & 16 & $67 \%$ & 8 & $33 \%$ \\
\hline $\begin{array}{l}\text { 1 Kondisi Awal (sesuai } \\
\text { dengan keadaan pada }\end{array}$ & & & & \\
$\begin{array}{l}\text { latar belakang) } \\
\text { 2 Siklus I }\end{array}$ & 17 & $71 \%$ & 7 & $29 \%$ \\
3 Siklus II & 18 & $75 \%$ & 6 & $25 \%$ \\
\hline
\end{tabular}

Tabel di atas dapat dijelaskan siswa yang belum tuntas belajar adalah sebagai berikut :

1. Pada kondisi awal sesuai dengan latar belakang penelitian, siswa yang belum tuntas sebanyak 8 siswa dari 24 siswa atau 33\%.

2. Pada siklus I, siswa yang belum tuntas sebanyak 7 siswa dari 24 siswa atau $29 \%$.

3. Pada siklus II, siswa yang elum tuntas sebanyak 6 siswa dari 24 siswa atau $25 \%$

Sedangkan siswa yang tuntas belajar adalah sebagai berikut:

1. Pada kondisi awal sesuai dengan latar belakang penelitian, siswa yang tuntas sebanyak 16 siswa dari 24 siswa atau $67 \%$.

2. Pada siklus 1 , siswa yang tuntas sebanyak 17 siswa dari 24 siswa atau $71 \%$.

3. Pada siklus II, siswa yang tuntas sebanyak 16 siswa dari 24 siswa atau $75 \%$. berikut :

Berdasarkan tabel diatas dapat dibuat diagram batang hasil belajar siklus II sebagai

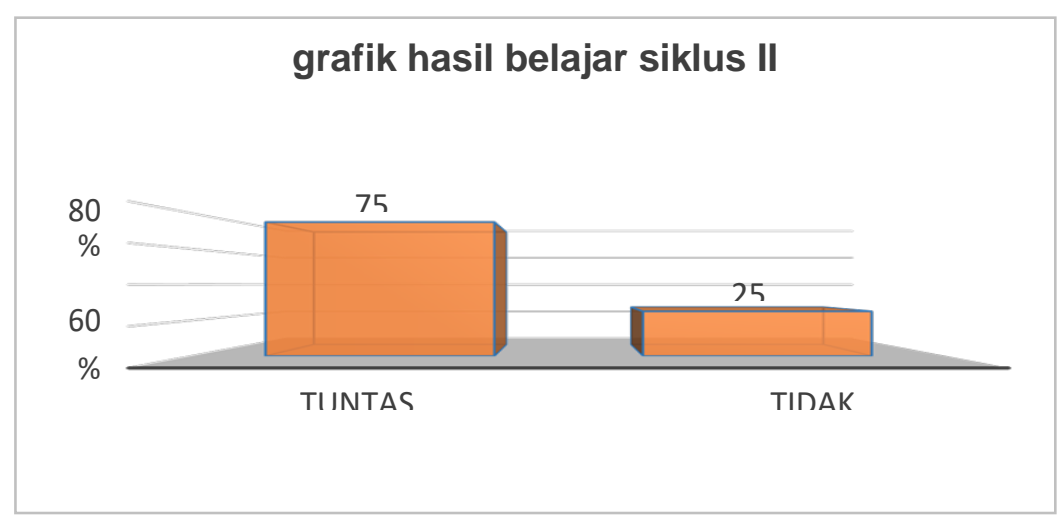

Gambar 2. Grafik hasil belajar siklus II 


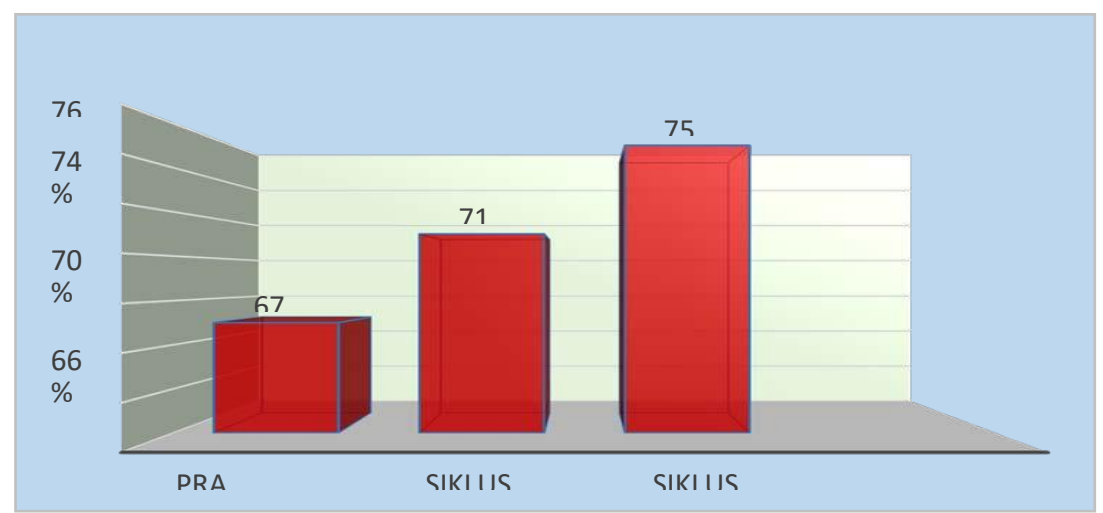

Gambar 3. Grafik perbandingan hasil belajar siklus I dan siklus II

\section{SIMPULAN}

Penggunaan media video powerpoint camtasia Studio 8 dapat meningkatkan hasil belajar siswa pada Tema 5 Pahlawanku kelas IV C SD Islam Al Azhar 22 Salatiga, hal ini dibuktikan dari hasil belajar pada siklus I yaitu siswa yang belum tuntas sebanyak 7 siswa dari 24 siswa atau 29\%, sedangkan siswa yang tuntas sebanyak 17 siswa dari 24 siswa atau $71 \%$. Pada siklus II, Pada kondisi awal sesuai dengan latar belakang penelitian, siswa yang belum tuntas sebanyak 8 siswa dari 24 siswa atau 33\%. Pada siklus II, siswa yang belum tuntas sebanyak 6 siswa dari 24 siswa atau 25\%, sedangkan siswa yang tuntas sebanyak 16 siswa dari 24 siswa atau 75\%. Ini artinya hasil belajar siswa meningkat dari siklus I ke siklus II.

Implikasi serta rekomendasi, hendaknya guru mengembangkan pembelajaran menggunakan media video powerpoint camtasia Studio 8 pada pelajaran yang lain.

\section{DAFTAR PUSTAKA}

Arif Sadiman., dkk. 2003. Media Pendidikan (Pengertian Pengembangan dan Pemafaatannya). Jakarta: CV Rajawali.

Arsyhar, Rayandra. 2012. Media Pembelajaran. Edisi 1. Jakarta:Referensi Jakarta

Asyhar, Rayandra 2012. Kreatif Mengembangkan Media Pembelajaran. Jakarta: Refrensi Jakrata.

Dimyati, Mudjiono. 1991. Belajar dan Pembelajaran. Jakarta: PT Rineka Cipta. Firdaus. 2006. Reformasi Pembelajaran Menuju Kualitas Insan Bertaraf Dunia. Pekanbaru: Witra Irzani.

Hamalik, Oemar. 2001. Proses Belajar Mengajar. Jakarta: Bumi Aksara. Hernawan, Asep Heri, dkk. 2009. Pengembangan Kurikulum dan Pembelajaran. Jakarta: Universitas Terbuka.

Majid, Abdul. 2014. Strategi Pembelajaran. Bandung: Remaja Rosdakarya.

M. Iskandar Putra, dkk. Pengembangan Media Pembelajaran Berbasisi Camtasia Studio Video CD INTERAktif Multimedia untuk MaTa Pelajaran Pemrograman WEBb di Jurusan Multimedia SMK NEGERI 3 Singaraja Prodi Pendidikan Teknik Elektro, Universitas Pendidikan Ganesha, Singaraja. Prodi Teknik Elektronika,Universitas Pendidikan Ganesha, Singaraja Jurnal Pendidikan Teknik Elektro Undiksha Vol. 6 No. 1, April 2017

Sudjana, Nana. 2008. Penilaian Hasil Proses Belajar Mangajar. Bandung: PT Remaja Rosdakarya.S 